\title{
Design and Implementation of Solar Power Controller for Real-time Utilization of Solar Energy with Reduced Transmission Line Loss
}

\author{
Md. Tanvir Ahammed \\ Dept. of EEE \\ Jessore University of Science \\ and Technology, Jessore, \\ Bangladesh
}

\author{
Md. Tariquzzaman \\ Dept. of EEE \\ Jessore University of Science \\ and Technology, Jessore, \\ Bangladesh
}

\author{
Md. Mehedi Hasan \\ Dept. of EEE \\ Jessore University of Science \\ and Technology, Jessore, \\ Bangladesh
}

\begin{abstract}
In this paper an efficient solar power controller (SPC), suitable for real-time applications with reduced transmission loss is proposed. The power generated by solar panel is not constant and varies with the solar radiation. So, a battery is used as back-up. The proposed SPC can maintain constant power at the load end irrespective of solar radiation. This proposed SPC consists of two step-up DC-DC converters along with MPPT controllers and storage batteries. The DCDC converters act parallel and share a common load in order to maintain constant power at load end. One of the DC-DC converters is connected directly to the solar panel output terminal and the other DC-DC converter is directly connected to the terminals of storage batter. MPPT controllers extract maximum possible electric power from solar panel. The converter steps up solar panel output voltage, normally unregulated DC voltage to a regulated $125 \mathrm{~V}$ at the load end. The output voltage of the converter can be adjusted to any desired level between $20 \mathrm{~V}-250 \mathrm{~V}$ DC voltages, for different applications. Here, $125 \mathrm{~V}$ is selected as solar loads are available at this voltage and transmission line loss reduced significantly. The proposed controller provides constant power at constant terminal voltage $(125 \mathrm{~V})$ and charges the battery when photo-voltaic (PV) generated power is greater than load requirements. During insufficient solar radiation or when panel output power is insufficient to maintain constant power at load end, the controller takes required power from the battery. This controller has almost constant efficiency about $87 \%$ at full load and reduces solar power transmission loss and overall cost of off-grid solar home system (SHS) for a multi-storied building.
\end{abstract}

\section{General Terms}

Efficient solar power controller, Reduced transmission power loss, Constant power at the load end irrespective of solar radiation, Storage battery, Regulated $125 \mathrm{~V}, 87 \%$ efficiency at full load.

\section{Keywords}

Solar transmission power loss, Solar power controller (SPC), MPPT, Step-up DC-DC converter.

\section{INTRODUCTION}

One of the major concerns in the power sector is day-to-day increasing power demand but the unavailability of enough resources to meet the power demand using the conventional energy sources which utilizes fossil fuel like oil, coal, gas etc. The cost of fossil fuel increasing day-to-day as their stock becomes depleted. The continuous use of fossil fuels has caused the fossil fuel deposit to be reduced and has drastically affected the environment depleting the biosphere and cumulatively adding to global warming [1]. For this reason, demand has increased for renewable sources of energy to be utilized along with conventional systems to meet the energy demand.

Solar energy is renewable, environmentally friendly and unlimited clean source of energy, effective utilization of solar energy can meet present and future demand of power. A PV module utilizes intensity of sunlight to produce electrical power. The problem involves, output power of a photo-voltaic (PV) module is not constant, and it varies with the variation of intensity of sunlight due to environmental conditions as well as man-made shading [2]. So, real-time utilization of solar energy and maintaining constant power from PV module is a challenge. Some application like solar water pump, solar powered electric vehicle needs real-time energy and constant power. In this paper a power electronics based solar power controller is proposed that can overcome insufficient solar radiation problem caused by variation of position of sun and shading effect due to clouds, buildings, trees etc. and makes real-time solar energy utilization. Solar energy is abundantly available that has made it possible to harvest it and utilize it properly. Solar energy can be a standalone generating unit or can be a grid connected generating unit depending on the availability of a grid nearby. A grid connected system is connected to a large number of independent grid and feeds energy directly into the grid. The optimum power received from the solar panel can be shared by a residential or commercial building. In case of standalone generating unit solar energy can be used to power rural areas where the availability of grids is very low. Another advantage of using solar energy is the portable operation whenever wherever necessary [3]. It is considered as a clean and environment friendly source of energy. By utilizing solar energy properly, the scarcity of power and emission of greenhouse gas can be eliminated.

In order to make efficient utilization of solar energy using PV module a lots of research work has been carried out. A costeffective MPPT system that can be directly integrated onto solar arrays has been presented [4]. A hybrid system for standalone solar application is presented in [5] which combines wind turbine and PV module. A battery less solar harvesting circuit for low power application has been presented in [6]. Reference [7] shows a directly water pumping system using solar module. Reference [8] presents a concept of Nano-grid which can be further aggregated in to Micro-grid. Battery is essential in standalone PV system 
applications such as street lights. Battery also helps to realize MPPT in standalone PV systems attributable to availability of storage to store excess power. A power conditioning unit is required to connect the battery with the PV source. PV has very low efficiency, so to utilize the PV power completely, it is desirable to use high efficiency power conditioning unit for PV systems [9]. Electric Vehicles (EV) are an alternative to conventional fuel powered cars and are efficient, more reliable, significantly less complex, cost effective, and environment friendly. To overcome the limitations of the EV, a new concept called as Hybrid Electric Vehicle (HEV) is proposed in the field of vehicle technology. Different green energy sources such as solar - PV, wind, fuel cell, battery, ultra-capacitor etc., are highly utilized as a primary energy sources in the modern HEV [10]. The solar energy converted into electricity with the help of PV arrays. The low output from PV array is stepped up using high gain DC-DC converter. The conventional buck-boost converter can be used but the limitation on duty cycle makes high gain not possible and multilevel buck-boost converter is necessary [11].

In this paper a DC based SPC is designed and implemented for real-time applications, as inverter less system for off-grid application is more efficient [12] and DC loads are more efficient and it reduces the total size and cost of PV and battery [13]-[15].

\section{PROPOSED SOLAR POWER CONTROLLER (SPC)}

Maintaining constant power at the load end for real time application such as solar powered electric vehicles (SPEV), solar driven water pumps (SDWP) is the main difficulty in PV systems. Here, a SPC is proposed that can provide constant power at load end even when solar radiation is insufficient. The block diagram of the proposed SPC is shown in Fig. 1.

\subsection{Controller Configuration}

The proposed SPC consists of two DC-DC converters (boost converter) along with MPPT controllers and storage battery. Two DC-DC converter operate parallel and share a common load in order to maintain constant power at load end. Fig. 1 shows the block diagram of the proposed SPC and the arrows shows the direction of power flow. Converter-1 acts as main source and converter- 2 acts as backup source. Converter-1 is connected to MPPT controller which is connected to solar panel and converter-2 is connected to MPPT charge controller along with backup battery.

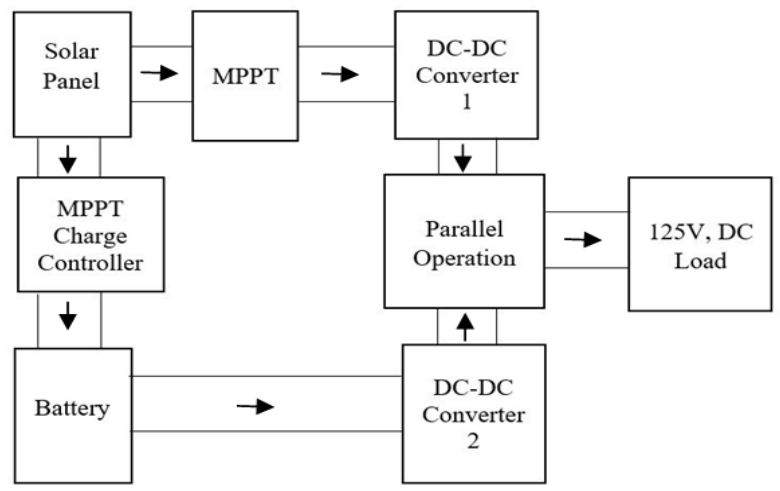

Fig 1: Block-diagram of proposed SPC
Table 1. Operation of Proposed SPC

\begin{tabular}{|l|l|l|l|}
\hline $\begin{array}{l}\text { Battery } \\
\text { status }\end{array}$ & $\mathbf{P}_{\mathbf{P V}}>\mathbf{P}_{\text {Load }}$ & $\mathbf{P}_{\mathbf{P V}}<\mathbf{P}_{\text {Load }}$ & $\begin{array}{l}\mathbf{P}_{\mathbf{P V}}= \\
\mathbf{P}_{\text {Load }}\end{array}$ \\
\hline $\mathrm{V}_{\text {bat }}=\mathrm{V}_{\text {bat_min }}$ & $\begin{array}{l}\text { Battery } \\
\text { charging }\end{array}$ & Battery idle & $\begin{array}{l}\text { Battery } \\
\text { idle }\end{array}$ \\
\hline $\mathrm{V}_{\text {bat }}=\mathrm{V}_{\text {bat_max }}$ & $\begin{array}{l}\text { Dummy } \\
\text { load }\end{array}$ & $\begin{array}{l}\text { Battery } \\
\text { discharging }\end{array}$ & $\begin{array}{l}\text { Battery } \\
\text { idle }\end{array}$ \\
\hline $\begin{array}{l}\mathrm{V}_{\text {bat_max }}> \\
\mathrm{V}_{\text {ba }}>\mathrm{V}_{\text {bat_min }}\end{array}$ & $\begin{array}{l}\text { Battery } \\
\text { charging }\end{array}$ & $\begin{array}{l}\text { Battery } \\
\text { discharging }\end{array}$ & $\begin{array}{l}\text { Battery } \\
\text { idle }\end{array}$ \\
\hline
\end{tabular}

Lead acid batteries can be used due to their low cost and maintenance. Both of the DC-DC converters are designed for $125 \mathrm{~V}$ DC load applications. A control system has been included to adjust the SPC output voltage to any desired value.

\subsection{Controller Operation}

The controller provides regulated $125 \mathrm{~V}$ DC terminal voltage at the load end under all environmental conditions. In the proposed SPC PV module acts as primary source and storage battery acts as backup source. The major operation of the proposed SPC, are as follows.

1. When PV module power generation is higher than load requirements converter- 1 remains in operation and drives the load connected to it. Converter- 2 remains idle. The excess PV generated energy is stored in the battery. The charge controller controls charging and discharging operation of the battery.

2. When PV module power generation is lower than load requirements converter-1 and converter-2 remains in operation and shares the load connected to it. Converter-2 remains idle. The excess energy previously stored in the battery starts discharging.

3. When PV module power generation is null, converter-2 remains in operation and drives the load connected to it. Converter-1 remains idle. The excess energy previously stored in the battery starts discharging. The operation of the proposed SPC is shown in Table 1.

\section{PERFORMANCE ANALYSIS AND EXPERIMENTAL RESULTS}

DC-DC converters are the most important part of the proposed solar controller. DC-DC converter steps up the PV module terminal voltage which is normally unregulated to a regulated $125 \mathrm{~V}$ DC to drive $125 \mathrm{~V}$ DC loads. The voltage stepping capability and efficiency of the DC-DC converter determines the effectiveness of the proposed SPC. The DCDC converter is designed using fly-back topology as fly-back topology requires relatively less components and has better efficiency. Fig. 2 shows a simplified circuit-diagram of a flyback DC-DC converter. The performance of the DC-DC converter is first analyzed in Section 3.1, then the performance of the proposed solar power controller (SPC) is analyzed in Section 3.2. The DC-DC converters are designed to provide $125 \mathrm{~V}$, terminal voltage $125 \mathrm{~V}$ is selected because DC LED lamps at different wattage rating are commercially available at $125 \mathrm{~V}$ and $125 \mathrm{~V}$ DC grid also exists. Due to voltage stepping line current reduces proportionally which 
reduces line loss and enables long distance transmission of power from remotely located solar systems.

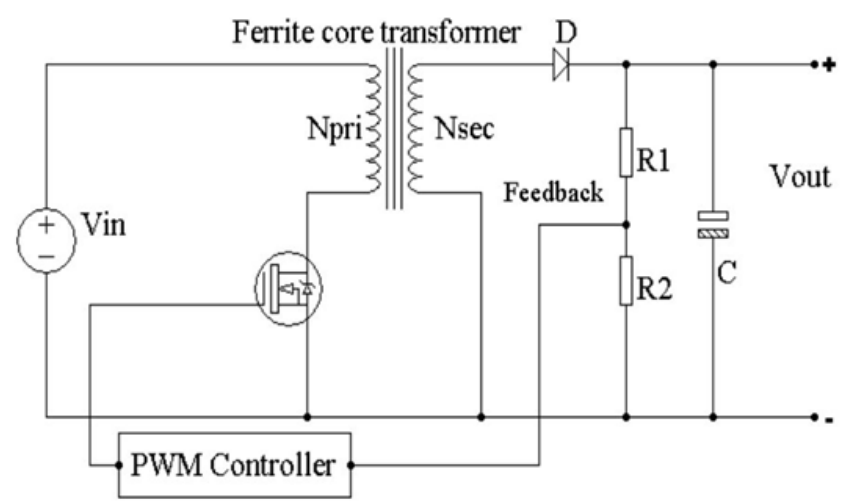

Fig 2: Fly-back DC-DC converter topology

\subsection{Performance Analysis of DC-DC}

\section{Converter}

For the purpose of analyzing the designed step-up DC-DC converter the following experimental data as shown in Table 2 has been taken. A variable DC power supply is used in this regard. These sets of data are then plotted in Fig. 3 and Fig. 4 for the purpose of performance analysis. Fig. 3, shows graphically the relationship between converter input voltage and output voltage. From this figure it is seen that the designed converter provides $125 \mathrm{~V}$ regulated DC terminal voltage from unregulated DC input voltages ranging from DC $8 \mathrm{~V}-16 \mathrm{~V}$. So, the designed converter is able to maintain constant voltage at load from unregulated source. The PWM controller controls the duty cycle automatically by taking feedback from converter's output terminal (Fig. 2). Thus, the terminal voltage of the converter remains constant at $125 \mathrm{~V}$. Fig. 4, shows graphically the relationship between converter input voltage and converter's conversion efficiency. The designed converter provides constant step-up output voltage $125 \mathrm{~V}$ from unregulated supply source, some power is lost in the conversion stage. The losses are mainly switching losses at MOSFET and Diode at high frequency $(50 \mathrm{kHz})$. From this figure it has been seen that the designed converter gives almost constant efficiency (about 89\%) at different input voltages when $11 \mathrm{~W}$ DC lamp used as load is used.

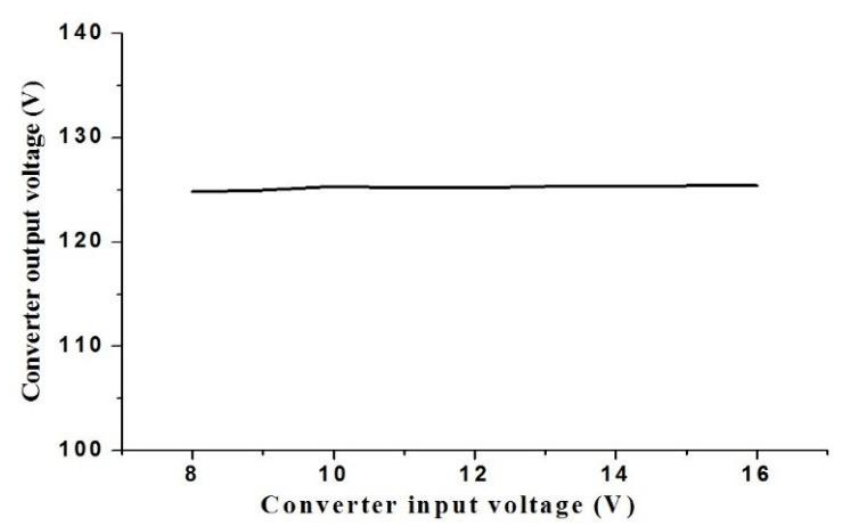

Fig 3: Converter input voltage vs output voltage characteristics for $11 \mathrm{~W}$ DC load

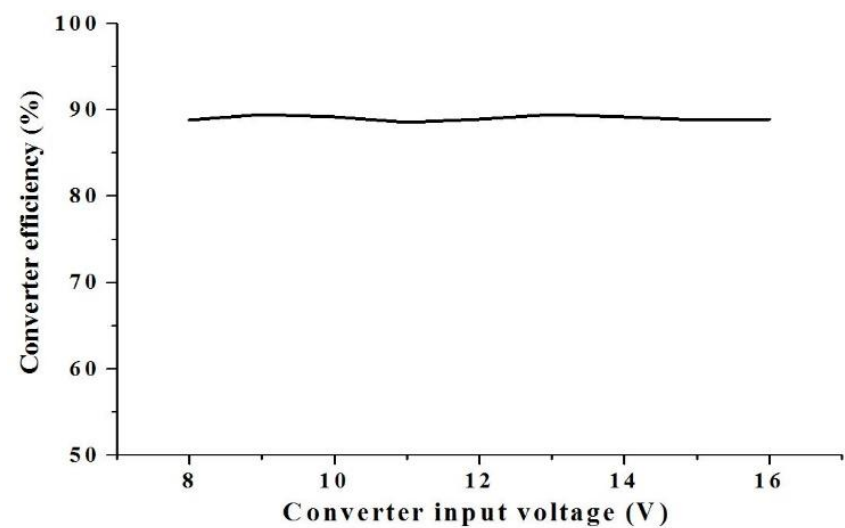

Fig 4: Converter input voltage vs converter efficiency ( $\%$ ) characteristics for 11W DC load

Table 2. Converter Input-output Characteristics for $11 \mathrm{~W}$ DC Load at Different Input Voltages

\begin{tabular}{|c|c|c|c|c|c|c|}
\hline $\begin{array}{c}\mathbf{V}_{\text {in }} \\
(\mathbf{V})\end{array}$ & $\begin{array}{c}\mathbf{I}_{\text {in }} \\
(\mathbf{A})\end{array}$ & $\begin{array}{c}\mathbf{P}_{\text {in }} \\
(\mathbf{W})\end{array}$ & $\begin{array}{c}\mathbf{V}_{\text {out }} \\
(\mathbf{V})\end{array}$ & $\begin{array}{c}\mathbf{I}_{\text {load }} \\
(\mathbf{A})\end{array}$ & $\begin{array}{c}\mathbf{P}_{\text {load }} \\
(\mathbf{W})\end{array}$ & $\begin{array}{c}\text { Efficiency } \\
(\%)\end{array}$ \\
\hline 16 & 0.84 & 13.4 & 125.4 & 0.09 & 11.286 & 88.90 \\
4 & & & & \\
\hline 15 & 0.89 & 13.4 & 125.4 & 0.09 & 11.286 & 88.90 \\
\hline 14 & 0.95 & 13.3 & 125.3 & 0.09 & 11.277 & 89.50 \\
\hline 13 & 1.02 & 13.3 & 125.3 & 0.09 & 11.277 & 89.20 \\
\hline 12 & 1.11 & 13.3 & 125.2 & 0.09 & 11.268 & 88.60 \\
\hline 11 & 1.21 & 13.3 & 125.2 & 0.09 & 11.268 & 88.90 \\
\hline 10 & 1.33 & 13.3 & 125.3 & 0.09 & 11.277 & 89.50 \\
\hline 09 & 1.48 & 13.3 & 125.0 & 0.09 & 11.250 & 89.24 \\
\hline 08 & 1.68 & 13.4 & 125.0 & 0.09 & 11.250 & 88.80 \\
\hline
\end{tabular}

3.2 Performance Analysis of the Proposed Solar Power Controller (SPC)

For the performance analysis of the proposed SPC as shown in Fig. 1, a solar panel and a storage battery is used. Specifications of the solar panel used for the purpose of analyzing the performance of the proposed SPC:

$\begin{array}{ll}\operatorname{Pmax} & =44 \mathrm{~W} \\ \text { Voc } & =19.2 \mathrm{~V} \\ \text { Isc } & =2.96 \mathrm{~A} \\ \text { Voperating } & =16.5 \mathrm{~V} \\ \text { Ioperating } & =2.67 \mathrm{~A}\end{array}$

Standard operating condition: $1000 \mathrm{~W} / \mathrm{m}^{2}, 25^{\circ} \mathrm{C}$

A $12 \mathrm{~V}, 7.5$ Ah lead acid battery is used as back-up source.

The proposed SPC is designed to overcome insufficient solar radiation, so it is required to verify the effectiveness of the SPC under different solar radiation. For performance analysis of the proposed solar power controller artificial shading by using a screen is used to vary the solar radiation. Solar radiation is varied by varying the distance between solar panel and shading screen. Table 3, shows the effect of solar 
radiation on load sharing between solar panel and battery of the proposed SPC.

Table 3. Effect of Solar Radiation on Load Sharing Between Solar Panel and Battery for 22 W DC Load

\begin{tabular}{|c|c|c|c|c|c|c|c|c|c|c|}
\hline \multirow{2}{*}{$\begin{array}{c}\text { Solar } \\
\text { radiation } \\
(\mathrm{W} / \mathrm{m} 2)\end{array}$} & \multicolumn{3}{|c|}{ Solar } & \multicolumn{3}{|c|}{ Battery } & \multicolumn{3}{|c|}{ Load } & \multirow{2}{*}{$\begin{array}{c}\text { Efficiency } \\
(\%)\end{array}$} \\
\hline & $\begin{array}{l}\mathrm{V}_{\text {solar }} \\
(\mathrm{V})\end{array}$ & $\begin{array}{l}I_{\text {solar }} \\
\text { (A) }\end{array}$ & $\begin{array}{l}P_{\text {solar }} \\
(\mathrm{W})\end{array}$ & $\begin{array}{l}\mathrm{V}_{\text {battery }} \\
\text { (V) }\end{array}$ & $\begin{array}{c}I_{\text {battery }} \\
\text { (A) }\end{array}$ & $\begin{array}{l}P_{\text {battery }} \\
\text { (W) }\end{array}$ & $\begin{array}{l}\mathrm{V}_{\text {load }} \\
(\mathrm{V})\end{array}$ & $\begin{array}{l}I_{\text {load }} \\
\text { (A) }\end{array}$ & $\begin{array}{l}\mathrm{P}_{\text {load }} \\
\text { (W) }\end{array}$ & \\
\hline 700.00 & 13.95 & 2.20 & 30.69 & 13.90 & 0.00 & 0.00 & 125.60 & 0.17 & 21.35 & 86.50 \\
\hline 600.00 & 13.76 & 1.90 & 26.14 & 13.80 & 0.00 & 0.00 & 125.70 & 0.17 & 21.37 & 87.00 \\
\hline 580.00 & 13.46 & 1.85 & 24.90 & 12.00 & 0.00 & 0.00 & 126.00 & 0.17 & 21.42 & 86.00 \\
\hline 270.00 & 7.90 & 1.30 & 10.27 & 12.00 & 1.20 & 14.40 & 125.70 & 0.17 & 21.37 & 87.00 \\
\hline 200.00 & 7.90 & 0.96 & 7.58 & 12.00 & 1.40 & 16.80 & 125.60 & 0.17 & 21.35 & 86.50 \\
\hline 105.00 & 7.90 & 0.50 & 3.95 & 12.00 & 1.73 & 20.76 & 125.70 & 0.17 & 21.37 & 87.00 \\
\hline 50.00 & 7.90 & 0.20 & 1.58 & 12.00 & 1.92 & 23.04 & 125.60 & 0.17 & 21.35 & 86.40 \\
\hline 30.00 & 7.90 & 0.10 & 0.79 & 12.00 & 2.00 & 24.00 & 125.60 & 0.17 & 21.35 & 86.40 \\
\hline 0.00 & 0.00 & 0.00 & 0.00 & 12.00 & 2.05 & 24.60 & 125.90 & 0.17 & 21.40 & 86.00 \\
\hline
\end{tabular}

Table 4. Experimental Data When Solar Power Generation is more than Load Requirements

\begin{tabular}{|c|c|c|c|c|c|c|c|}
\hline \multirow{2}{*}{$\begin{array}{c}\text { Solar radiation } \\
(\mathbf{W} / \mathbf{m} 2)\end{array}$} & \multicolumn{3}{|c|}{ Solar } & \multicolumn{3}{|c|}{ Battery (charging) } & Load \\
\cline { 2 - 9 } & $\begin{array}{c}\mathrm{V}_{\text {solar }} \\
(\mathrm{V})\end{array}$ & $\begin{array}{c}\mathrm{I}_{\text {solar }} \\
(\mathrm{A})\end{array}$ & $\begin{array}{c}\mathrm{P}_{\text {solar }} \\
(\mathrm{W})\end{array}$ & $\begin{array}{c}\mathrm{V}_{\text {battery }} \\
(\mathrm{V})\end{array}$ & $\begin{array}{c}\mathrm{I}_{\text {battery }} \\
(\mathrm{A})\end{array}$ & $\begin{array}{c}\mathrm{P}_{\text {battery }} \\
(\mathrm{W})\end{array}$ & $\begin{array}{c}\mathrm{P}_{\text {load }} \\
(\mathrm{W})\end{array}$ \\
\hline 700.00 & 13.95 & 2.20 & 30.69 & 13.90 & 0.61 & 8.50 & 21.35 \\
\hline 600.00 & 13.76 & 1.90 & 26.14 & 13.80 & 0.28 & 4.00 & 21.37 \\
\hline
\end{tabular}

Table 3, shows experimental data of the proposed SPC for $22 \mathrm{~W}$ DC load. From Table 3, it is seen that solar power generation decreases as solar radiation decreases and the designed SPC takes the required lack of power from storage battery in order to maintain constant power at the load. To understand the overall process graphically Fig. 5 and Fig. 6 are drawn. Fig. 5, shows that the proposed SPC can maintain constant power at load irrespective of solar radiation caused by shading effect or environmental conditions. When available solar power is enough to maintain load, the battery remains idle. The battery comes into operation when solar power generation is insufficient to maintain the load demand. Under no shading condition the solar power generation is maximum $30.69 \mathrm{~W}$, so it easily drives the load without the help of the battery. For solar radiation $700 \mathrm{~W} / \mathrm{m} 2,600 \mathrm{~W} / \mathrm{m} 2$ and $580 \mathrm{~W} / \mathrm{m} 2$ battery remains in charging state for that battery delivers no power to the load, the solar panel alone drives the load. During insufficient solar radiation the controller allows the battery to discharge and maintains constant power at load. So, the designed SPC takes only the surplus of power from the battery and capable of maintain constant power at load end. Fig. 5, also shows turn on and turn off points of the battery. Turn on point (left to point A in Fig. 5) shows on condition of the battery that means the battery starts to discharge and provides surplus of power at the load. The turn off point (right to point A in Fig. 5) shows the off condition of the battery that means the remains idle and if the solar power generation is more than the load requirements the excess power can be stored in the battery as shown in Table 4. Point B in Fig. 5 indicates that only battery drives the load. At point $\mathrm{B}$ solar power generation is null. Between point A and B load sharing between solar panel and battery takes place. Separate colors are used in Fig. 5 to indicate power curves of solar panel, battery and load respectively. Fig. 6, shows that the proposed controller has almost constant efficiency (around 87\%), the efficiency remains almost constant under different solar radiation. So, the controller

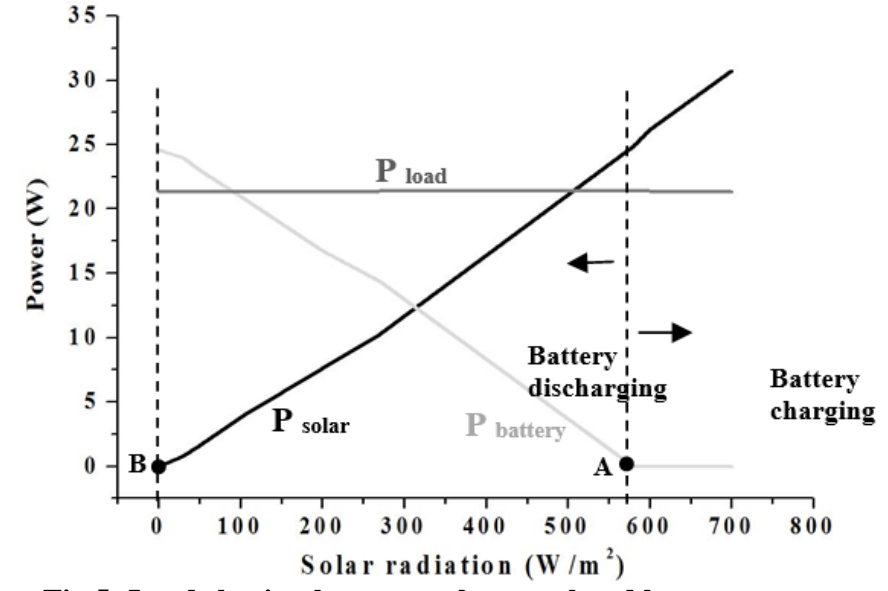

Fig 5: Load sharing between solar panel and battery

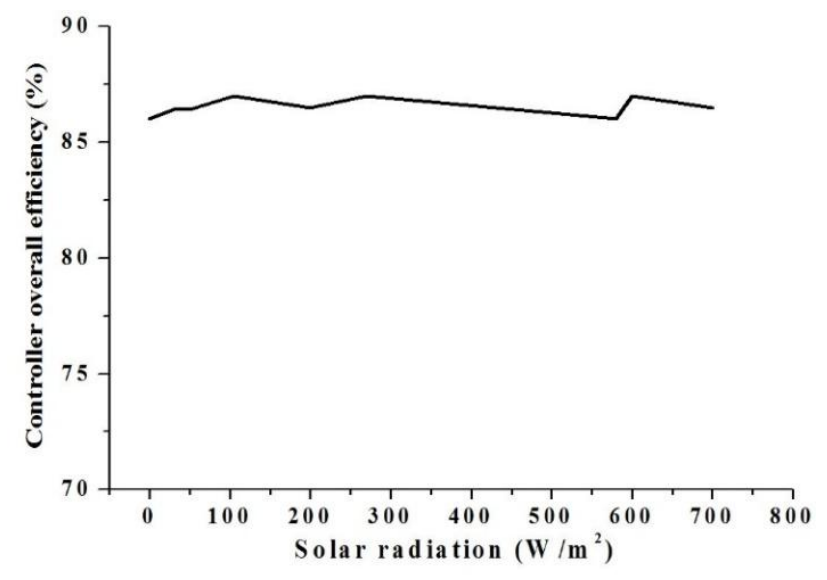

Fig 6: Effects of solar radiation on SPC's overall 


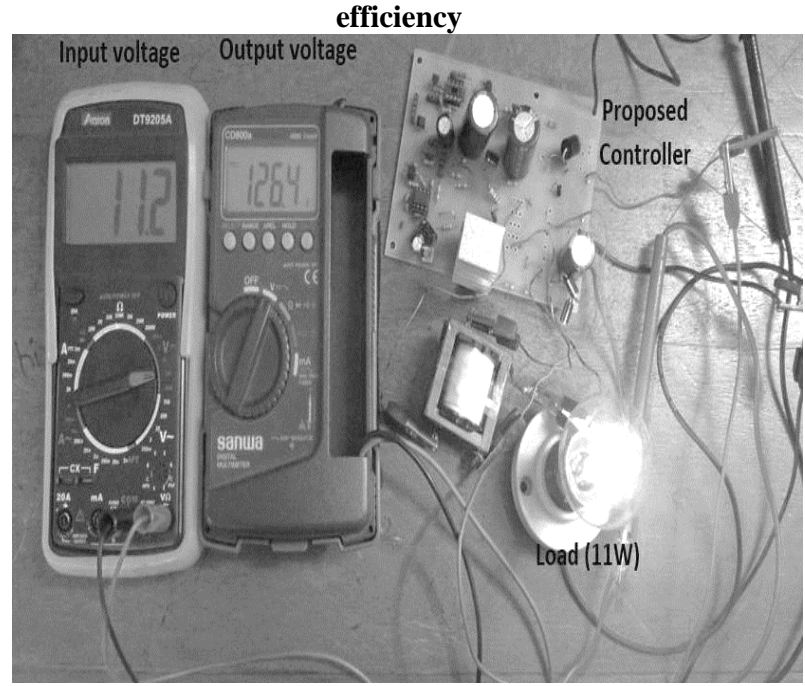

Fig 7: Hardware Implementation

efficiency is independent of solar radiation and the proposed SPC can overcome insufficient solar radiation problem. The hardware implementation is shown in Fig. 7. The main hardware components are ferrite core transformer (ETD-39), current mode PWM controller (UC3843), ultrafast-diode (UF5408), resistors, capacitors etc.

\section{CONCLUSION}

In this work a solar power controller has been proposed for real-time utilization of PV energy. The controller eliminates insufficient solar radiation problem and capable of maintaining constant power at load the side. The proposed controller has been designed and implemented successfully. The effectiveness of the controller has been tested for $21 \mathrm{~W}$ load at different solar radiation. As solar radiation decreases the controller takes required power from battery. The controller boosts unregulated solar panel terminal voltage to a regulated $125 \mathrm{~V}$ at the load side so, it reduces line loss compared to $12 \mathrm{~V}$ system. MPPT controllers are used to obtain maximum available power from solar panel and to control charging operation of battery. MPPT charge controllers also protects the battery from over charge and discharge. The proposed controller provides real-time utilization of PV energy and maintains constant power at the load side with almost constant efficiency (about 87\%) at different solar radiation. This controller allows real time utilization of solar energy from solar panel, whereas conventional controllers first store the solar power into storage battery then used for different applications. As the designed SPC gives real time utilization of solar energy is suitable for solar driven electrical vehicles, solar driven water pump etc.

\section{REFERENCES}

[1] M. Veerachary, "Fourth-order buck converter for maximum power point tracking applications", IEEE transactions on aerospace and electronic system, vol. 47, No. 2. pp. 896-911, April 2011.

[2] J. K. H. Hussein, I. Muta, T. Hoshino, and M. Osakada, "Maximum photovoltaic power tracking: An algorithm for rapidly changing atmospheric conditions," in Proc. Inst. Elect. Eng.-Gen. Tranmiss. Distrib. vol. 142, no. 1, pp. 59-64, Jan. 1995.
[3] S. Zhong Yi He, Hong Chen, "Integrated solar controller for solar powered off-grid lighting system", Elsevier, Energy Procedia 12, pp. 570-577, September 2011.

[4] D. P. Hohm and M. E. Ropp, "Comparative study of maximum power point tracking algorithms using an experimental, programmable, maximum power point tracking test bed," in Proc. 28th IEEE Photovoltaic Spec. Conf., 2000, pp. 1699-1702.

[5] MouS. Tanezaki, T. Matsushima, and S. Muroyama, "Stand-alone hybrid power supply system composed of wind turbines and photovoltaic modules for powering radio relay stations," in Proc. IEEE INTELEC, Oct. 2003, pp. 457-462.

[6] Davide Brunelli, Clemens Moser and Lothar Thiele, Member IEEE, "Design of a Solar-Harvesting Circuit for Battery less Embedded Systems". IEEE Trans. on Circuits and Systems, vol. 56, 11 Nov. 2009.

[7] H. Dehbonei, S. R. Lee, and H. Nehrir, "Direct energy transfer for high efficiency photovoltaic energy systems. Part I: Concepts and hypothesis,"IEEE Trans. Aerosp. Electron. Syst., vol. 45, no. 1, pp. 31-45, Jan. 2009.

[8] Mo J. Enslin, M. Wolf, "Integrated photo-voltaic maximum power point tracking converter," IEEE Trans. Ind. Electron. , vol. 44, no. 6, pp. 769-773, Dec. 1997.

[9] T. Esram and P. Chapman, "Comparison of PV array maximum power point tracking techniques," IEEE Trans Energy Convers. vol. 22, no. 2, pp.439-449, June 2007.

[10] Rong-Jong Wai, Wen-Hung Wang, "High performance Stand-Alone Photovoltaic Generation System, " Industrial Electronics, IEEE Trans. vol. 55, no. 1, pp. 240-250, Jan. 2008.

[11] J Cam Pham, Kerekes, T. Teodorescu, "High efficient bidirectional battery converter for residential PV systems", Power Electronics for Distributed Generation Systems (PEDG), 2012 3rd IEEE International Symposium on, vol., no., pp.890-894, 2528 June 2012.

[12] Anusha Ramachandran ; Sairam Mannar ; Ashok Jhunjhunwala, "Inverterless Solar- DC system design for off- grid and near off-grid Indian homes",IEEE Conference on Sustainable Green Buildings and Communities (SGBC), 18-20 Dec. 2016.

[13] Hoppmann, J., et al., The economic viability of battery storage for residential solar photovoltaic systems - A review and a simulation model. Renewable and Sustainable Energy Reviews, 2014. 39: p. 1101-1118.

[14] Bhatia, M. and N. Angelou, Beyond Connections: Energy Access Redefined, in ESMAP Technical Report 008/15, ESMAP, Editor. 2015, ESMAP: Washington.

[15] Brock Glasgo, Inês Lima Azevedo , Chris Hendrickson, "How much electricity can we save by using direct current circuits in homes? Understanding the potential for electricity savings and assessing feasibility of a transition towards DC powered buildings". ELSEVIER, Applied Energy 180 (2016) 66-75. 